\title{
THE IMAGE OF AN INDEPENDENT WOMAN (IN THE EXAMPLE OF CHARLOTTE BRONTE'S JANE EYRE AND RASHOD NURI'S CHOLI KUSHI)
}

\section{Saida Tashmuradovna Ismatova}

1st Year Student Of Foreign Language And Literature,'Denau Institute Of Entrepreneurship And Pedagogy

Bakhtigul Ibodullayevna Sodikova

Teacher Of The Department Of Foreign Languages And Literature, Denau Institute Of Entrepreneurship And Pedagogy

Barno Khushbokovna Elmirzayeva

Teacher Of Denau Institute Of Entrepreneurship And Pedagogy

\section{ABSTRACT}

This article embodies the image of a strong independent woman, reflected in works from two different cultures, namely Charlotte Bronte's Jane Eyre and Rashod Nuri Gultegin's Cholikushi. Both works are examples of autobiographical work. It reflects the path that Jane Eyre and Ferede have taken throughout their lives, how they can continue their lives without falling through hardships and obstacles, that is, the lives of women who have been able to restrain their patience and perseverance. Life never stops, it never stops. Happiness can be achieved only by overcoming the difficulties of life. Every woman has her own place in society and worldview. It is no exaggeration to say that these two works reflect the same two views. That is, women are the beauty of the world.

KEYWORDS: - Protagonist , contradicted society , masculine , feminine , "father-man", "father-surrogate", women.

\section{INTRODUCTION}

Jane Eyre (originally published as Jane Eyre: an Autobiography) is a novel by English writer Charlotte Bronte, published under the pen name "Currer Bell" in 1847, in London. Jane Eyre is a Bildungsroman which follows the experiences of its heroine, including her growth to adulthood and her love for Mr. Rochester, the brooding master of Thornfield Hall.

In a time when women were considered little more than social adornments and bearers of offspring, Charlotte Bronte bravely contradicted society through her writing. Her novels speak volumes for the oppressed woman; thus establishing Charlotte Bronte as one of the first modern women of her time. Charlotte Bronte was progressive in her beliefs. In her novel Jane Eyre, Charlotte Bronte created the character of Jane of a slight woman, in all respects plain, modest, morally strong and intelligent. Like the author, Jane's isolation created her persona, providing her with the necessary survival skills. Jane does not need a man to make her feel worthy; instead, she carries her self-worth in her mind and determination. Through Jane, Bronte exhibits resentment toward a society that has 
CURRENT RESEARCH JOURNAL OF PHILOLOGICAL SCIENCES 2(5): 91-95,

May 2021 DOI: https://doi.org/10.37547/philological-crjps-02-05-20

ISSN 2767-3758

(C)2021 Master Journals

\section{Crossref do) 81 Google}

Accepted25 ${ }^{\text {th }}$ May, 2021 \& Published 31 ${ }^{\text {th }}$ May, 2021

scorned her, while maintaining a detachment toward humanity as a whole.

The novel can be seen as a journey of Jane finding her true self. Jane fights convention by resisting the male dominance, on her quest for identity and independence she remains true to herself by putting herself first and caring for her own wellbeing, even though she is longing for love and kinship. It is a fact that woman authors during the time were not received as seriously as men; however, as Currer Bell, Charlotte had the freedom to create her characters the way she wanted. Concealed by anonymity, she created heroines with genuine ideas and erudite views, who, above all, respected themselves, and weren't afraid to declare it. For Charlotte Bronte, it was the ideal emotional outlet.

According to the novel Jane Eyre, the image of women always stands behind the men with the social class variations among them. It clearly shows that women mostly doing a household job rather than being a financial resources in a family. Even though Jane Eyre in an exception in this topic, she is trying her best to make her own financial by working as a governess which in that time, the occupation of governess itself could raising Jane's position in society. It can not be denied that Jane still relies on men's character.

Charlotte Bronte urged women not to linger on such problems; though the literary world must be grateful she did not heed her own advice. It was through her discontent that the character of Jane Eyre was born. When Jane ultimately falls in love, she embraces the notion of love itself, not the label or profits derived from it.

However, Jane will not sacrifice her morals or self-respect for any man. In essence, she will not sacrifice herself. It is imperative to her to remain true to herself. Nothing can tempt Jane in this respect: wealth, status, or love.

"I care for myself. The more solitary, the more friendless, the more unsustained I am, the more I will respect myself." (Bronte 301).

Like Jane, Charlotte herself was determined to marry a man she respected. In fact, she refused several offers of marriage that would have afforded her a life of ease, simply because the offers did not come from men she deemed her equal, or rather she felt them intellectually and morally deficient. She believed that a good woman, like any decent man, could not live without self-respect.

This quote shows an unconventional and radical feministic view of men and women during the Victorian, patriarchal, time of Bronte. It displays Jane's longing for equality and independence. The quote is also a way for the author to vent her repressed longing for a less restricted life and her feministic view through her protagonist.

Even though Rochester makes it clear to Jane that he is older and more experienced, Jane still stands up to him and questions his right to command her during their discussions. Rochester, with his seniority of 20 years and his superior power, appears as a "father-man". He could be the projection of the author's longing for her ideal man which was a "father-surrogate" (Dooley 241). Jane's unconscious could be looking for a father surrogate to compensate her fatherless childhood. Rochester tests Jane by spreading a rumour that he will marry Blanche Ingram causing Jane to feel insecure in regards to her looks. Blanche is a beautiful woman and Jane is aware of how the society and men rate women regarding how beautiful they are; beautiful women have a higher value than unattractive women. Beauty in a woman is regarded more important than intellect, because a woman was expected to be an ornament without much opinion.

Jane even though he already has a wife and is not able to enter another legally binding marriage it is a way of trying to exploit her. During the 
CURRENT RESEARCH JOURNAL OF PHILOLOGICAL SCIENCES 2(5): 91-95,

May 2021 DOI: https://doi.org/10.37547/philological-crjps-02-05-20

ISSN 2767-3758

(C)2021 Master Journals

\section{Crossref do) 81 Google}

Accepted25 ${ }^{\text {th }}$ May, 2021 \& Published 31 ${ }^{\text {th }}$ May, 2021

wedding preparations Jane realizes the great social difference and how she is to be financially dependent on Rochester; Rochester reminded her of a "sultan", who "bestow on a slave his gold and gems" (Bronte 237). When the marriage is stopped Jane turns down a comfortable life as Rochester's mistress because even though she loves him and wants to be with him she will be dependent and in a sense imprisoned as a slave. To Jane independence is very important and she will not sacrifice her integrity and dignity.

Jane finds her relatives and finally belongs to a family. After running away from Thornfield, Jane is homeless and without any possessions, she wanders lonely, freezing and hungry. I agree with Gilbert and Gubar that Jane's situation symbolizes "the nameless, placeless and contingent status of women in a patriarchal society" (Bronte 364). Jane does however stumble on the home of her cousins at Marsh End, the name representing the end of her search; she will be able to find her identity and place in the world at last. The wailing infant of Jane's recurring dream (Bronte 194, 263) is finally silenced. The dream she had while at Thornfield could symbolize Jane that cannot be comforted, representing the suffering and loneliness she has experienced in her childhood which she carries with her into adulthood. Staying with her newly found good relatives helps her to heal and find a stable ground; she overcomes the anger she has regarding the abuse she suffered as a child living with her bad relatives; the Reed family. At Marsh End, some of her wishes come true; she finally belongs to a family, she is intellectually stimulated by studying together with her cousins Diana and Mary, and her dream of starting a small school comes true with the help of her cousin St. John Rivers, who seeks her company more frequently and to begin with seems to offer a viable alternative to the life offered by Rochester.

Women at the time were brought up and conditioned that men were powerful and women followers that suppressed their own identity. Jane's eagerness to please a product of that she has never before felt true belonging could be one of the reasons why she has such difficulties to fend herself from St. Johns increasing power over her. "I felt his influence in my marrow - his hold on my limbs" (Bronte 359). Jane agrees to follow him to India to become a missionary as his helper but not his wife as she feels that he does not love her, she feels as he rather hates her and marrying send her to a premature death (Bronte 365). His persistence is strong and she is getting "hard beset by him" but in a different way she had been by Rochester, to yield would have been an error of judgment (Bronte 370).

Jane and Rochester finally enter a marriage of two equals which was unheard of at the time. I feel that this could be the reason why they live isolated in the forest without any social life to speak of. I also think that it was clear that Jane did not care for the superficial social life she was forced to be an observer of at Thornfield when Rochester was putting on his show of courting Blanche. In the end Jane found her place in life: "No woman was ever nearer to her mate than I am [.] to be together is for us to be at once as free as in solitude, as gay as in company" (Bronte 399). Jane found the love and kinship she longed for without sacrificing her own identity and independence. Rochester adds interest to Jane's life with the intellectual stimulus of their evening conferences, which she was lacking before he entered the scene. Jane and Rochester can be considered quite equal intellectually, however to begin with many inequalities exist.

Jane stays true to herself during her quest for identity and independence. The frightening night in the Red Room causes her grow up overnight and having experienced true fear she is no longer afraid to stand up for herself against the patriarchal society. Miss Temple teaches her to repress her rage. Through the death of Helen and 
CURRENT RESEARCH JOURNAL OF PHILOLOGICAL SCIENCES 2(5): 91-95,

May 2021 DOI: https://doi.org/10.37547/philological-crjps-02-05-20

ISSN 2767-3758

(C)2021 Master Journals

\section{Crossref do) 81 Google}

Accepted25 $5^{\text {th }}$ May, 2021 \& Published 31 ${ }^{\text {th }}$ May, 2021

Bertha Jane is freed from the male ideal of female identity; the angel-in-the-house and the demon. Jane's quest for identity and independence comes together at Marsh End. She finds her good relatives at Marsh and overcomes the injustices by the bad relatives at Gateshead. Jane finds a stable ground and overcomes the rage repressed in her unconscious.

Jane returns to Rochester and finally offers her unconditional love to him when he essentially has nothing left. Blind and penniless, Rochester can only offer himself, proving that for Bronte love transcends the societal expectations of marriage, and is based instead on mutual respect and love. Bronte, in her subtlety, wrote of simple women, who relied upon the respect of themselves, rather than society, to provide fulfilment in their lives. Through her characters, Bronte gave the gift of the modern woman, a woman determined to make her own way, and live her life by her own set of standards, dictated not by society but by herself, and herself alone.

Jane surpasses all of the gentlemen in the novel to become the character with the truest qualities and the ability to deal with any situation presented to her with grace and dignity. She becomes a heroine in the true sense in that she not only saves herself multiple times, but she saves her hero from a life of desperate solitude. This evolution in her character would not have been possible, however, if it were not for the fact that there are no real gentlemen in the novel who would have taken Jane's place and swept her off her feet. Thus she is equal to a gentleman if not above him, and that allows the reader to see her as the strongest character in the novel.

The events in the novel take place on the eve of the First World War. The protagonist of the work, Ferede, is separated from her parents at a young age and faces various difficulties in life. Ferede falls in love with her cousin Comron. Comron also loves her, but due to family circumstances, they cannot be together. Ferede goes to a remote village to work as a teacher. At the end of the play, the two young people finally reach each other ("Chalikushi").

Jane from Jane Eyre and Ferede from Çalıkuşu (The Wren) are both orphans who learned to stand up for themselves in an early age. So, here we have two women alone in the society. Both Victorian Society and late 19th and early 20th Century Turkish society had similar rules and roles for women. A woman had the role of a mother and a wife. She should not learn or think. But what we see in those two novels are girls who are educated. That is an important factor. Those similarities create a worldwide view for us about women in those centuries. When Jane tries to educate herself by looking at paintings, she is dragged into a room to be punished and when Ferede runs on the beach, her cousin warns her by saying "Are you crazy Ferede. If someone sees us, we would be in shame!" (Güntekin 60, Bronte 12) This is the way of society's control over the girls to put them in their "rightful" places. Both Jane and Ferede were different for a normal woman in their societies. While Jane Eyre's aunt calls her "unnatural", Ferede's teacher calls her "the Wren" (Güntekin 22, Bronte). Both novels, apart from each other within time and space, are the same in essence. Therefore cross-cultural analysis of those novels in a gendered outlook is important. They both describe the same lives female characters in the center with a very similar view of women and they both criticise their societies for the way it looked their women.

\section{REFERENCES}

1. Bronte Charlotte, Jane Eyre, 1847. London: Wordsworth Classics, 1999.

2. Bronte, Charlotte. Jane Eyre. Wordsworth 
CURRENT RESEARCH JOURNAL OF PHILOLOGICAL SCIENCES 2(5): 91-95,

May 2021 DOI: https://doi.org/10.37547/philological-crjps-02-05-20

ISSN 2767-3758

(C)2021 Master Journals

Crossref do) 80 Google

Accepted25 ${ }^{\text {th }}$ May, 2021 \& Published 31 ${ }^{\text {th }}$ May, 2021

Editions Limited. 1992. Print.

3. Bronte, Charlotte. Jane Eyre. Alfred A Knopf Inc. New York: 1991.

4. "Beams and shadows" (Nur va soyalar) was written by Robindranar Thakur in 1888 or 1900. And then this story was published a number of newspapers in India.

5. "Chalikushi" (Choliqushi) was written by Rashod Nuri Guntekin in Turkey. This novel was come out in 1922. "Cholikushi" was translated from Turkish into Uzbek by Mirzakalon Ismailiy.

6. "Shubkha" was written by Robindranat Thakur in India. This story was come out in 1961. "Shubkha" was translated by Uygun. 